\title{
Kurumsal Kimlik Aracı Olarak Facebook: Türkiye'deki Sivil Toplum Kuruluşları (STK) Üzerine Bir Değerlendirme*
}

\author{
M. Canan Öztürk \\ doçent, anadolu üniversitesi, halkla ilişkiler ve reklamcılık bölümü \\ mozturk@anadolu.edu.tr \\ Emine Şardağı \\ araştırma görevlisi, anadolu üniversitesi, iletişim bilimleri fakültesi \\ halkla ilişkiler ve reklamclık bölümü \\ eminesardagi@anadolu.edu.tr
}

\section{Abstract \\ Facebook as a Corporate Identity Tool: An Evaluation on Non Government Organizations (NGO) in Turkey}

The purpose of this study is to reveal which corporate identity elements of Non Government Organizations'(NGO) more reflects in Facebook. For this purpose, 178 foundations and associations operating in Turkey's official Facebook accounts have been examined in terms of corporate identity elements. Elements of corporate identity are addressed in four dimensions as corporate behavior, communication, design and philosophy. Corporate culture and image elements, which are the areas of interaction of corporate identity, are also included in the study in order to investigate the corporate identity through a holistic perspective. The study employs descriptive research method. Content analysis method was adopted to gather the data. As a result, it has been revealed that NGOs are mostly reflecting corporate communication and design elements in Facebook

* Bu çalışma, Emine Şardağı tarafından 2016 yılında Anadolu Üniversitesi Sosyal Bilimler Enstitüsü Halkla İlişkiler ve Reklamcilık ABD'nde tamamlanan Yüksek Lisans tezinden türetilmiştir. 
keywords: corporate identity, social media, Facebook, non-governmental organizations (ngo)

\section{Résumé}

Facebook comme outil d'identité institutionnelle: une évaluation des Organisation Non Gouvernementale (ONG) en Turquie

Le but de cette étude est de révéler quels éléments d'identité institutionnelle reflètent le plus les Organisation Non Gouvernementale (ONG) sur Facebook. Ainsi, les comptes officiels Facebook des 178 fondations et associations opérant en Turquie ont été examinées en termes d'éléments d'identité institutionnelle. Les éléments de cette identité ont été traités selon le comportement de l'institution, la communication, la conception et la philosophie. La culture et l'image d'entreprise sont des domaines d'interaction de l'identité institutionnelle. Afin de traiter les données, on a utilisé une méthode d'analyse de contenu. Les résultats de cette recherche ont montré que ces ONG utilisaient Facebook plus en termes de communication et de design.

mots-clés: identité institutionnelle, médias sociaux, Facebook, organisations non gouvernementales

\section{Öz}

Bu çalışmanın amacı, Sivil Toplum Kuruluşlarının (STK) kurumsal kimliğin hangi unsurlarını Facebook'ta daha fazla yansıttı̆̆ını ortaya koymaktır. Bu amaçla Türkiye'de faaliyet gösteren 178 vakıf ve derneğin resmi Facebook hesapları kurumsal kimlik unsurları açısından incelenmiştir. Kurum kimliğinin unsurları kurumsal davranış, iletişim, tasarım ve felsefe olmak üzere dört boyutta ele alınmıştır. Kurumsal kimliğin etkileşim alanları olan kurum kültürü ve imaj unsurları, kurumsal kimliğin bütünsel bir perspektiften ortaya çıkarılması için çalışmaya dâhil edilmiştir. Araştırmada betimleyici araştırma tasarımı kullanılmıştır. Verilere ulaşabilmek için içerik analizi yöntemi kullanılmıştır. Araştırma sonucunda, STK'Iarın kurumsal iletişim ve tasarım unsurlarını Facebook'ta daha fazla yansıttığı belirlenmiştir.

anahtar kelimeler: kurumsal kimlik, sosyal medya, facebook, sivil toplum kuruluşları (STK) 


\section{Giriş}

Tıpkı her insanı diğerlerinden ayıran bir kimliği olduğu gibi kurumları da birbirinden ayıran kimlikleri vardır. Kurumlar günümüzün rekabet koşulları içinde rakiplerinden farklılaşmak ve fark edilebilmek için çeşitli tasarım unsurlarını, davranış kalıplarını, iletişim yöntemlerini kullanarak kendini paydaşlarına anlatma çabası içindedir. Kurumların kim olduğu, ne yaptığı ve nasıl yaptığı (Olins, 1995) ile ilgili özelliklerini yansıtan kurumsal kimlik, kurum içinde çalışanlar arasında bütünleşmeyi sağlarken kurum dışındaki paydaşların kurumu benzerlerinden ayırt etmesine katkıda bulunmaktadır. Bununla birlikte paydaşların bir ürün ya da hizmet seçiminde kurumu tercih etmesine, kuruma yönelik imaj ve itibarın oluşmasına zemin hazırlamaktadır.

Sosyal medya, çoğunlukla web 2.0 tabanlı teknolojiler ile ortaya çıkan ve kullanıcıların diğer insanlarla iletişime ve etkileşime geçtiği, içerik üretip paylaştığı bir yapıyı ifade etmektedir. Web 2.0 teknolojilerinin ortaya çıkmasıyla birlikte hayatımızda önemli bir yer tutan sosyal medya, kullanıcı sayısının her geçen gün arttığı ve bireylerin sadece birbirleriyle etkileşim kurdukları bir ortam değil, aynı zamanda kurumların da hedef kitlelerine ulaşabilmek için kullandıkları ortamlardan biri olmuştur. Kullanıcının daha aktif bir konumda olduğu bir yapıyı ifade eden sosyal medya, bununla birlikte kurumların kendilerini paydaşlarına anlatmaya çalıştıkları alan haline gelmiştir.

Sivil toplum kavramının ne olduğuna yönelik olarak üzerinde uzlaşılan bir tanım olmasa da "aile, devlet ve piyasayı temsil eden, gönüllü olarak ortaya çıkan ve amacı kamu yararını artırmak olan birey, kurum ve kuruluşların toplamından ibaret" olduğu belirtilmektedir (Özdemir vd., 2009, s. 157). Türkiye'de yapılan bir araştırma Sivil Toplum Kuruluşlarının (STK) ${ }^{1}$ toplumla ilişkisinde;

- STK'ların mesajlarını halka iletme konusunda bilgi eksiği olması,

- Çoğu kez halkın anlamayacağı bir dille konuşulması,

- Hemen tüm STK'ların iletişim konusunda eksikliklerinin olması,

- Çalışmalarında kullanılan görsel malzemelere yeterli özen gösterilmemesi,

- Insanların beklentilerinin göz önüne alınmaması konularında zayıf noktalar olduğu ortaya çıkmıştır (Esen, 2014, s. 7).

Sivil Toplum Kuruluşları (STK) kendi amaçlarını yerine getirmek amacıyla çeşitli faaliyetlerde bulunurken halkla ilişkiler uygulama alanlarından faydalanmakta ve buna paralel olarak da interneti etkin bir şekilde kullanmaya çalışmaktadır. Sadece duyuruma destek olması ve örgütle ilgilenen kişilerle iletişim için olanaklar sunması yönünden bile sosyal medya ortamları STK'lar ile ilgili medyanın ve toplumun ilgisizliği gibi engellerin aşılması için bugüne kadar elde edilmemiş olanaklar sunmaktadır (Onat, 2010, s. 109).

1 Çalışmanın sonraki kısmında Sivil Toplum Kuruluşları STK kısaltmasıyla kullanılmıştır. 
STK'lar bu zamana kadar gönüllülerin katkılarıyla kendi sesini geleneksel ortamlarda kısmen duyurabilme şansını elde etse de reklam açısından düşünüldügünde maliyetlerin çok yüksek olması ve STK'ların varlığının bağışlara dayanması geleneksel ortamda çok aktif olamamalarına sebep olmuştur. Bu doğrultuda bakıldığında yeni bir mecra olarak karşımıza çıkan sosyal medyanın STK'ların karşılaştığı bu türden sorunlar ve örgüt içindeki iletişimle ilgili engelleri azaltabilme konusunda imkânlar sağlayacağı söylenebilir. Sosyal medya ticari kurumlar açısından önemli olduğu kadar, varlığı bağışlara dayanan STK'lar için daha fazla kişiye ulaşma, bağış toplayabilme, gönüllü katılımı sağlama gibi konularda fırsatlar sunan önemli bir ortamdır. Özellikle geleneksel medya ile ulaşmakta zorluk çektiği hedef kitlelere etkileşimin yoğun olduğu, hızı ve daha düşük maliyetlere dayanan bu ortamlar aracılığıyla sesini duyurabilmesi mümkündür. Bu ortamlarda kim olduğunu, ne yaptığını ve nasıl yaptığını göstermek STK'ların geniş bir kitleye kendisini anlatabilmesine, kullanıcıları faaliyetleri hakkında bilgilendirmesine, düşüncelerinin daha fazla kişi tarafından paylaşılmasına katkıda bulunmaktadır. Bu nedenle STK'lar açısından burada önemli olan nokta; bu ortamlarda kurumsal kimliklerini doğru yansıtmayı başarmaktır.

Yapılan bu çalışma ile Türkiye'de faaliyet gösteren STK'ların son dönemlerde yaygın şekilde bir halkla ilişkiler aracı olarak kullanılan sosyal medya ortamlarından biri olan Facebook'taki kurumsal kimlik unsurlarına yönelik olarak bir değerlendirmenin ortaya konulması amaçlanmıştır. Literatürde STK'lara yönelik yapılan çalışmalarda daha çok STK'ların sosyal medya kullanım amaçları, sosyal medyanın STK'lar açısından sağladığı avantajlar ve sosyal medyanın neden-nasıl kullanıldığına yönelik çalışmalara yer verildiği belirlenmiştir (Seo, Kim ve Yang, 2009; Waters vd., 2009; Curtis vd., 2010; Water ve Jones, 2011; Lovejoy ve Saxton, 2012; Young, 2017). Ayrıca sosyal medyanın kurumlar tarafından nasıl kullanıldığına dair yapılan çalışmalar olsa da sosyal medyayı kurumsal kimlik temelinde ele alan çalışmaların sınırlı sayıda olduğu belirlenmiştir. Bu çalışmalardan bir tanesi konuyu kavramsal çerçeve üzerinden ele alırken (Devereux, 2017), bazıları da ticari kurumlar üzerinden ele almıştır (Sundararajan vd., 2012; Kuvykaite ve Piligrimiene, 2013; Krake, 2014; Gianfiglio, 2015). Çalışmanın yapıldığı dönemde STK'ların sosyal medyayı kurumsal kimlik temelinde nasıl değerlendirdikleri, kendilerini bu platformlarda nasıl yansıttıklarına yönelik olarak yapılan herhangi bir çalışmaya rastlanılmamıştır. Bu durum, bu anlamdaki boşluğun doldurulması açısından çalışmanın önemini ortaya koyacak niteliktedir. Araştırma Türkiye'de faaliyet gösteren STK'lar özelinde ele alınmıştır. STK'ların resmi Facebook hesapları içerik analizi yöntemiyle kurum kimliğinin unsurları ve etkileşimde olduğu alanlar dâhilinde incelenmiştir. Elde edilen veriler doğrultusunda STK'ların sosyal medyada kurumsal kimliklerini daha etkin biçimde kullanmalarını sağlamak için öneriler sunulmuştur.

Sosyal medya, kurumların paydaşlarıyla etkileşimde bulunmak için yoğun olarak kullandıkları ve kimliklerini yansıtması gereken ortamlardan biri olmasına rağmen bu konuda yapılan çalışmaların yeterli sayıda olmaması bir eksiklik olarak 
görülmektedir. Özellikle yapılan çalışmaların ticari kurumlar üzerinden ele alınması varlığı bağışlara dayanan STK'lar için bir dezavantaj olarak görülebilir. Çünkü ticari kurumların sosyal medyanın özellikleri doğrultusunda kendi kimliklerini oluşturabilmeleri ve nasıl kullanmaları gerektiğine yönelik profesyonel destek alabilme durumları söz konusudur. Ancak STK'ların zaten sınırlı para kaynaklarının olması bu anlamda destek alabilmesini zorlaştırıcı bir unsurdur. Bu nedenle sadece ticari kurumlar için değil, STK'lar içinde sosyal medyada kurumsal kimlik ve kimliği yansıtmaya yönelik hangi bilgilerin yer alması gerektiği gibi konularda akademik çalışmalara yer verilmesi bu anlamda ortaya çıkan eksikliğe katkıda bulunabilir. Çalışmadan elde edilen bulgular, özellikle bağışlar ile faaliyet gösteren STK'ların maliyet açısından uygun, hızlı ve etkili olan sosyal medya ortamında kendi kurumsal kimliklerini daha iyi nasıl ifade edebilecekleri konusunda yol gösterici niteliktedir.

\section{Kurum Kimliği Kavramı}

Kurum kimliğini Abratt (1989) bir kurumu diğerlerinden tanınabilir ve ayırt edilebilir yapan bir dizi davranışsal ve fiziksel işaretler olarak tanımlarken, Argenti ve Forman (2002), bir kurumun logosu, ürünleri, hizmetleri, mağazaları, üniformaları vb. ile yayılan ve kurum tarafından çeşitli hedef kitleleriyle iletişim sağlamak için yarattığı birtakım somut öğeleri olan görsel görünümü olarak ifade etmiştir (Westcott Alessandri, 2001 ve Rodamir vd., 2014). Doğru bir kurumsal kimlik inşa etmenin, hedef kitlelerin kurumun kim olduğu, ne iş yaptığı ve topluluk için kattığı değerin ne olduğunu anlamasına yardımcı olduğu belirtilmektedir (Belasen, 2008, s. 46). Tarihsel süreç içerisinde kurum kimliğinin kavramsallaştııımasına yönelik çeşitli yaklaşımlar bulunmaktadır. IIlk zamanlarda sadece tasarım olarak ele alınan kurum kimliği görsel öğeler doğrultusunda tanımlanmıştır. Ancak sonraki dönemlerde kimliğin görsellikten çok daha fazlasını ifade ettiği ve aslında kültüre dayalı olarak oluşturulan bir yapı olduğu belirtilmiştir. Günümüze gelindiğinde ise kurum kimliği artık stratejik bir araç olarak ele alınarak kurumun iletişim programlarına rehberlik ettiği bir unsur olduğu görülmektedir. Bir kurum kimliği stratejisinin geliştirilmesinde etkili olan nedenleri Okay; şu başlıklar altında toplamıştır (2003, s. 70):

- Yeni oluşum/yeniden kuruluş

- Değişiklik

- Görev profilinin veya ürün paletinin değişmesi

- Kuruluşun yeniden yapılanması

- Yönetimin değişmesi

- İşyerinin taşınması ve yeniden organizasyon

- Kuruluşların birleşmesi.

Kurumsal kimlik uygulamaları kurumlara içsel ve dışsal olmak üzere çeşitli avantajlar sunmaktadır. İçsel avantajları; çalışan motivasyonu sağlaması, nitelikli ve kaliteli personelin kuruma kazandırıması, çalışanların yapabilecekleri konusunda cesaretlendirilmesi, kurum kültürüne adaptasyonu sağlaması, kuruma özgü ve 
rekabette fark yaratacak bir hikâye oluşturulabilmesi olarak sıralanabilir. Dışsal avantajları ise, dış hedef kitlede güvenirlilik etkisi oluşturması, şirkete yönelik eksik, hatalı ya da yanlış bilgilerin düzeltilebilmesi, güçlü kurumsal markaların ortaya çıkması, finansal olarak iyi bir şirket olarak algılanmasına yardımcı olması, sürdürülebilir rekabet avantajını sağlaması, pazar payını arttırarak yatırımcıları kuruma çekme, kriz durumlarında koruyucu bir rol üstlenmesi olarak ele alınabilir.

\section{Kurum Kimliğinin Etkileşim İçinde Olduğu Alanlar}

Kurum kimliğinin etkileşim içinde olduğu alanlar; kurumsal kültür, kurumsal imaj ve kurumsal itibar olmak üzere üç ana başlık altında ele alınmıştır.

\section{Kurumsal kültür}

Goffee ve Jones (2002, s.35) kurum kültürünü “bir kuruluşun kurumun, bölümün, takımın ortak değerleri, sembolleri, inançları ve davranışları olarak tanımlamaktadır. Kurum kültürü, kurum içerisinde görev alan tüm çalışanların güvendikleri, inandıkları ve kendilerini ait hissettikleri bir ortam yaratacak ortak değerlerin ortaya çıkarılması, yaşatılması ve benimsenmesini amaçlamaktadır (Uzunoğlu vd., 2009, s.23). Kiriakidou ve Millward (1999) kültürün kurumsal kimliğin gelişimi ve kabulünde önemli bir rolü olduğunu savunmakla birlikte değerler, ürün/hizmetlerin kalitesi, kurum performansı ve kurumsal davranışın kurum kimliğinin göstergeleri olduğunu belirtmektedirler.

\section{Kurumsal imaj}

En basit ifade ile kişi, kurum ya da durum hakkında ortaya çıkan görüşlerin toplamı olan imaj kavramı, rekabetin yoğun olduğu bir ortamda kurumlar açısından önem taşımaktadır. Kişilerin kuruluş hakkındaki duydukları, gördükleri ya da doğrudan kuruluşla ilişki kurdukları, edindikleri kanının görüntüsü "kurumsal imajı" oluşturmaktadır (Sabuncuoğlu, 2010, s.90).

Kurum kimliği ile kurum imajı arasındaki ilişkiye bakıldığında; kurum kimliği kurumun kendini dışarıya nasıl ifade ettiği, nasıl tanındığı olarak değerlendirilmekte iken kurum imajı kurumun dışarıdan nasıl algılandığı, zihinsel olarak nasıl kavrandığı ile ilgilidir. Kurumsal kimlik, bir kurumun hedef kitlesine ilettiği mesajların bütününü oluştururken, kurumsal imaj, bu mesajların hedef kitle açısından oluşturduğu algıların bir bütünüdür. Kurum kimliği çabaları kurum tarafından gerçekleştirilen somut hareketlerdir. Kurum imajı ise kurumun hedef kitlesinin kurum hakkında sahip olduğu somut düşüncelerini, dışarıdaki grupların kurumu nasıl algıladığını ya da kurumun "olmasını istediği" durumu ifade etmektedir. STK'ların kurumsal imajlarının oluşumunda oluşturdukları misyonları çerçevesinde sundukları çözüm önerilerinin ve bunun toplum içindeki yansımasının önemi büyüktür. Olumlu bir imaja sahip olunması STK'ların toplum içerisinde kabul edilmesini, gelir ve gönüllü desteği elde etmelerini kolaylaştırmaktadır. 


\section{Kurumsal itibar}

Fombrun (1996), itibarı bir şirketin en değerli varlığı olarak ele almakta ve itibarı soyut bir zenginlik biçimi olarak ifade etmektedir. İtibar, firmalara ürünün yüksek fiyatla ücretlendirmesi, daha düşük pazarlama faaliyetleri ve karar verme sürecinde daha fazla özgürlük gibi konularda rekabetçi avantaj sunmaktadır.

Suher (2012, s.118) bir kurumun paydaşlarına (tüm hedef kitlelerine) tanıtılmasında kurum kültürü, kurum imajı, kurum kimliği ve kurum itibarı olmak üzere dört tane unsurun önemli olduğunu belirtmektedir. Kimlik uygulamalarıyla oluşturulmaya çalışılan imaj uzun dönemde şirkete beraberinde itibarı getirmektedir. İtibar, kurum tarafından uzun vadede ve tutarlı davranışların bir sonucu olarak oluşmakta ancak doğru şekilde değerlendirilemediğinde kısa sürede kaybedilmektedir. STK'lar için toplumda yaptığı faaliyetler kapsamında iyi ve yararlı bir kurum olarak algılanma isteğinin olması kurumsal itibarın önemini giderek arttırmaktadır.

\section{Kurum Kimliği Unsurları}

Her ne kadar kurum kimliği başlangıçta sadece tasarımdan oluştuğuna yönelik bir algı olsa da tek başına sembollerden oluşmamakta ve farklı unsurların biraraya gelmesiyle bir anlam kazanmaktadır. Bu çalışmada kurum kimliğinin unsurları Kiessling ve Spannagl (1996) tarafından belirtilen kurumsal davranış, iletişim, tasarım ve felsefe olmak üzere dört boyutta ele alınmıştır (Akt. Okay, 2003).

\section{Kurum felsefesi}

Kurum kimliğinin en temel unsurları arasında yer alan kurum felsefesi, kurumun kendisi hakkındaki düşüncelerinden oluşmaktadır ve şirketin üst düzey yöneticileri tarafından oluşturulan inançlar, amaçlar, vizyon, misyon ve sloganın toplamıdır. Kurum felsefesi, işletmenin vizyonunun ve misyonunun yer aldığı, işletme davranışlarının, kurallarının, faaliyetlerinin ve faaliyet hedeflerinin belirtildiği işletme çalışanlarına ve yöneticilerine yol gösteren, işletme paydaşlarına kurum hakkında bilgi veren bir yol göstericidir (Sabuncuoğlu, 2010, s. 85). STK'lar açısından bakıldığında ise kurum felsefesi yapılan faaliyetlerin altında yatan, temel var oluş nedenleri olarak ifade edilebilir. Stratejik bir anlayış doğrultusunda kendi varoluş nedenlerini net olarak ifade edebilmeleri STK'ların değerleri ve ilkeleri doğrultusunda hareket edebilmelerine ve hedeflerine ulaşmaya yardımcı olur.

\section{Kurumsal davranış}

Kurumsal davranış, organizasyondaki kişi ve grupların "nasıl ve neden davrandıkları" sorularına cevap bulmak, ilişkilerin kurulmasında kullanılan araçlar ve bunlarla kurumsal yapı arasındaki etkileşimlerle ilgilidir (Derin ve Demirel, 2010, s.16). Kuruluşun karşı karşıya kaldığı çeşitli durumlarda ne şekilde davranması gerektiğini belirleyen kurumsal davranış, kurumun felsefesinden etkilenerek oluşmaktadır. STK'ların hedef kitleleriyle iletişime geçerken ya da faaliyetlerini 
sürdürmesi sırasında gösterdikleri davranış şekilleri, verdikleri tepkiler kurumun değerlendirilmesinde ve imajının oluşumunda önemli bir etkiye sahip olduğu söylenebilir.

\section{Kurumsal iletişim}

Kurumsal iletişim, yönetim disiplini içinde gelişen ve kurumsal mesajların tutarııı̆ını ve şeffafı̆̆ını sağlamaya yönelik bir yaklaşımdır. Kurumsal iletişim karmaşık bir yapıdır ve kurumun çeşitli hedef kitleleri ile olan iletişim tarzı ile ilgilidir. İstenilen imaja ulaşabilme ve rekabette fark avantajı yaratma konusunda önemli bir rol oynamaktadır (Melewar, Karaosmanoğlu, Peterson, 2005, s.63). STK'lar açısından bakıldığında uzun vadede, sistematik ve kuruma yönelik olumlu bir imaj oluşturarak bu imajı korumaya yönelik olarak gerçekleştirilen kurumsal iletişim kurumdan çevresine yönelik olarak yapılacak tüm iletişim faaliyetlerinin koordine edilmesini, bilgi ve düşünce alışverişini ifade etmektedir. Sosyal medya ise bu bağlamda STK'ların iletişim faaliyetlerini gerçekleştirmesinin düşük maliyetli ve hızlı bir yolu olarak değerlendirilebilir. STK'lar günümüzdeki iletişim araçlarının yaygınlığı düşünüldügünde artık paydaşlarıyla daha fazla etkileşime ve diyaloğa girmek zorunda oldukları bir durumdadır. STK'ların günümüz teknolojileri ve sosyal medya kullanımın artması nedeniyle paydaşlarıyla iletişimi daha kolay bir hale gelmiştir. Dolayısıyla bu ortamları etkileşime ve iletişime açık bir şekilde kullanmaları imaj ve itibar oluşumunda önemli bir avantaj sunabilir.

\section{Kurumsal tasarım (Dizayn)}

Kurumsal tasarım bize bir kuruluşun kendisini görsel olarak nasıl ifade ettiğini göstermektedir. Kurumsal kimliğin önemli ana unsurlarından biri olan kurumsal tasarım, genellikle görsel kimlik olarak da adlandırımakta ve kurumun kimliğini göstermek için yaptığı her şeyde kendi özel karakterlerini vurgulaması olarak değerlendirilmektedir. Kurumsal tasarım, kurumun veya markanın etkili bir biçimde algılanarak hafızalara yerleşmesine, firmanın ürünlerinin tanınmasına, hedeflenen çevrelerde saygınlık kazanmasına, firmanın kurum kimliğini ve kültürünü açığa çıkarmaya yardımcı olmaktadır (Aktuğlu, 2004, s.140). STK'ların kendilerini yansıtacak nitelikte özel karakterler kullanması fark edilmesini kolaylaştıran, bilinirliliğini artıran ve akılda kalııılığı sağlayan güçlü bir araçtır.

\section{Sosyal Medya Kavramı ve Facebook}

Sosyal medya, temelleri web 2.0 teknolojileri ve felsefesi üzerine kurulmuş olan, içeriğin tüketicilerce yaratılmasına ve paylaşılmasına olanak sağlayan internet tabanlı uygulamalar olarak tanımlanabilir (Tuncer, 2013, s.15). Bir başka tanıma göre, bilgi ve görüşleri toplayıp paylaşmak için konuşma ortamlarını kullanan insanların eylem, uygulama ve davranışları olarak ele alınmaktadır (Sharif, Troshanı ve Davidson, 2015, s. 53). 
Web 2.0 ve sosyal medyanın hayatımıza kattığı önemli unsurlardan biri pasif konumda olan izleyiciyi aktif bir konuma getirerek onun da içerik yaratmasına, değiștirmesine ve paylaşmasına imkân veren olanakları sunmasıdır. İnsanların birbirleriyle etkileşim kurmalarına imkân sağlayan sosyal medya, düşünce ve fikirlerin özgürce paylaşılmasını, tüketicinin üretici konumuna gelmesini sağlayan bir yapıyı ifade etmektedir. Botha, Farshid, Pitt (2011) sosyal medyanın internet ve web tabanlı teknolojileri monolog olan iletişimi sosyal bir diyaloğa dönüştürmek için kullandıklarını ifade etmektedir. Sosyal medya, web 2.0 teknolojisinin sunduğu imkânlarla birlikte birtakım özelliklere sahiptir. Bu özellikleri Mayfield (2008), katııı, açıklık, karşıııkı konuşma, topluluk ve bağlanmışlık olarak sıralamaktadır. Kietzmann ve arkadaşları (2011) ise kimlik, diyalog, paylaşım, mevcudiyet, ilişkiler, itibar ve gruplar olarak ele almaktadır. Sosyal medyanın bireylerarası iletişime imkân sağlaması, hızlı ve anında güncellenebilmesi, maliyetinin düşük olması, kullanımın kolay olması, katılımı ön plana çıkarması, her türlü içeriğin paylaşıımasını sağlaması gibi birçok avantajı bulunmaktadır. Buna rağmen sosyal medya çeşitli dezavantajları da beraberinde getirmektedir. Bu dezavantajlar arasında bilgilerin kontrolü ve takibinin zorlaşması, sahte hesapların sayılarının artmasının ortaya çıkardığı sorunlar, kişisel verilerin korunmasına yönelik endişelerin yaşanması, nefret söylemlerinin kolaylıkla yayılmasına imkân vermesi vb. yer almaktadır.

Tsimonis ve Dimitriadis (2014) kurumların sosyal medya ile niçin ilgilenmeleri gerektiğine yönelik olarak altı neden belirlemiştir. Bunlar (1) sosyal medyanın hızla büyümesi (2) popülaritesinin artması, (3) viral gücü, (4) rakiplerin sosyal medyada var olması, (5) merkezin sosyal medya stratejisi ve (6) düşük maliyet olarak sıralanmaktadır. Benzer bir şekilde Parveen vd. 2015 yılında yaptıkları çalışmada sosyal medya kullanımının kurumlara müşterileri için daha iyi hizmet sunma ve kurumların performansı üzerinde etkiye sahip olduğu, bilgiye erişebilmeyi kolaylaştıııp maliyeti azalttığını belirtmiştir.

2004 yllında Mark Zuckerberg tarafından kurulan Facebook, sosyal ağ siteleri içerisinde en yaygın olarak kullanılan ortamlardan biridir. We Are Social'ın her yıl sosyal ve dijital trendleri ele alan araştırmasına göre 2016 yılında bir önceki yıla göre aktif internet kullanıcı sayısı \%12, aktif mobil sosyal medya kullanıcı oranında \%10 oranında artış meydana gelmiştir. Bununla birlikte dünyada 3 milyardan fazla internet kullanıcısı bulunmakta ve bunun 2 milyardan fazlası sosyal medya kullanmaktadır. Aynı araştırmadan elde edilen bir diğer sonuca göre; Facebook 1,5 milyar aktif kullanıcısıyla dünyanın en popüler sosyal ağı olarak görülmektedir². Bu açıdan bakıldığında dünyada en geniş yayılma hızına sahip sosyal ağ olan Facebook, medya tarihindeki diğer araçlarla karşılaştırıldığında oldukça sıra dışı olarak değerlendirilebilir.

Facebook kullanımının bu kadar yaygın olarak kullanılmasında sağladığı avantajların etkili olduğu söylenilebilir. Karademir ve Alper (2011) bu avantajları aşağıdaki gibi sıralamaktadır:

2 https://wearesocial.com/uk/special-reports/digital-in-2016/ (Erişim Tarihi: 06.07.2017). 
- Kullanıcılara zengin bir çeşitliliğe sahip çoklu bir ortam sağlaması,

- Farklı sitelerle bağlantı kurarak paylaşım yapmanın kolay olması,

- Grup, etkinlik ve uygulama gibi seçenekler sunarak geniş topluluklarla iletişim kurulabilmesi,

- Farklı paylaşım siteleri ve mail hesapları ile bağlantı kurmayı sağlaması,

- Çevrimiçi ve çevrimdışı sohbet imkânı sağlaması,

- Ticari amaçlı kullanımlarda istediğimiz ürünleri inceleme ve karşılaştırma olanağı sunması,

- Mobil cihazlar için destek sağlayan bir altyapıya sahip olması,

- Görselliğinin olması ve Türkçe dil desteği sunması.

Sosyal medyada markaların kullanabileceği birçok platform bulunmaktadır. Her bir platformun ise kendine ait özellikleri bulunmaktadır. Burada önemli olan her bir platformun sahip olduğu özellikler doğrultusunda kurumsal kimliği ifade etme aracı olarak doğru şekilde kullanılmasıdır.

\section{Literatürde Yer Alan İlgili Araştırmalar}

Sosyal medyanın kurumlar tarafından nasıl kullanıldığına yönelik yaplan çalışmaların sayısı fazla olsa da sosyal medyayı kurumsal kimlik temelinde ele alan çalışmaların sınırlı sayıda olduğu görülmektedir. Literatürde yapılan çalışmalara bakıldığında kurumsal kimlik ile ilgili çalışmaların daha çok kurumların web siteleri üzerinden içerik analizi yöntemine başvurularak yapıldığı ve web siteleri üzerinden kurumsal kimliklerini nasıl yansıttıkları üzerinde odaklandıkları görülmektedir.

Sosyal medyada kurumsal kimliğe yönelik yapılan çalışmalardan biri Sundararajan vd. tarafından 2012 yılında yapılmıştır. Bu çalışmada sosyal medya platformlarının önemi ve kurumların kimliklerine etkisi tartışıımıştır. Buna göre kurumların çevrimiçi ve sosyal medyada kimliklerini etkili bir şekilde yönetememelerinin çeşitli sebepleri olduğu belirtilmiştir. Bu nedenlerden biri, kurumların hala sosyal medyayı ürün ya da hizmetlerini pazarlayacakları bir alan olarak görmeleri ve paydaşlarıyla etkileşim kurmak için bir platform olarak görmemeleridir. 2013 yllında Kuvykaite ve Piligrimiene sosyal medyadaki iletişimin kurumların imaj oluşumuna etkisini bankalar üzerinden incelemiştir. Araştırma ile kurum kimliği unsurları kullanılarak sosyal medyada kurumsal imajın oluşturulabileceği, imaj oluşturma sürecinin kimlik ve onun unsurlarının belirlenmesi aracıığıyla başladığı sonucuna ulaşılmıştır. Sosyal medyada kurumsal kimliğe yönelik yapılan çalışmalardan bir diğeri Kostamo tarafından 2013 yılında yapılmıştır. Bu çalışmada da şirketlerin kimliklerini sosyal medyada nasıl oluşturup yönettikleri incelenmiştir. Çalışma sonucunda sosyal medya özelliklerinin kurumsal kimliğin tüketiciler ve diğer sosyal medya paydaşları ile işbirliği geliştirmesine olanak sağladığını, kurumsal kimliğin sosyal medyada oluşturulması ve yönetilmesinin tek yönlü bir süreç olmadığını, karşılıklı etkileşim ve işbirliğine dayanan süreci dinamik hale getiren bir geribildirim öğesine sahip olduğu belirtmektedir. 2014 yılında Ivo Krake tarafından yapılan diğer bir çalışmada 
ise, kurumların sosyal medya platformlarında kurumsal görsel kimliklerini nasıl kullandıkları ve tutarlı bir görsel kimliğin sosyal medya kullanıcıları üzerindeki etkisi incelenmiş ve en tutarlı şekilde kullanılan unsurların logo ve arka plan resmi olduğu sonucuna varılmıştır. Gianfiglio (2015) yııında yaptığı tez çalışmasında havayolu şirketlerinin YouTube içerikleri aracılığıyla kurumsal kimliklerini nasıl yansıttıklarını incelemiştir. Çalışmasında YouTube'da yayınlanan içeriklerin kurumsal kimliğin belirli değerlerini güçlendirdiğini ortaya çıkarmıştır.

Devereux vd, (2017) sosyal medyanın kurumların kurumsal kimliklerini oluşturup geliştirmeleri için birçok yeni yol ortaya çıkardığını, sosyal medya ve mobil teknolojilerdeki gelişimin kurumsal kimliğin ön plana çıkmasına, öneminin giderek artmasına katkıda bulunduğunu belirtmektedir. Burada önemli olan sosyal medya uygulamalarının kurumsal kimlik temelinde yapılması ve işlevsel bir fonksiyon olarak kullanımının gerçekleştirilmesidir. Sosyal medyanın markalar açısından yoğun olarak kullanımasının marka bilinirliğinin üzerinde olumlu etkisinin olduğu, marka farkındalığının yaratılmasını ve marka değerini etkilediği belirtilmektedir.

\section{Sivil Toplum Kuruluşları Açısından Sosyal Medyanın Önemi}

Sosyal medya ortamları sadece bireyler arası etkileşimde değil aynı zamanda örgütlerin amaçları doğrultusunda mesajların yayılmasında kitle iletişim aracı niteliğine kavuşmuştur (Onat, 2010, s.104). STK'lar geleneksel yollarla ulaşamadığı hedef kitlelerine bu ortamlar aracılığıyla ulaşarak mesajlarını onlara duyurabilme, farkındalık sağlama ve onları eyleme geçirecek imkânlara sahip olmuştur. Curtis vd. (2010), STK'larda çalışan halkla ilişkiler uzmanları için sosyal medyaya adapte olmanın sınırlı para kaynakları olmasından dolayı yararlı bir alan olarak görüldügünü belirtmektedir. Ayrıca, sosyal medyanın viral özelliği STK'ların destekçi sayılarını hızla artırması, daha çok insana ulaşılması, duyurmak istediği mesajların yayılımının ve tüm bunların gözlemlenmesinin diğer mecralara oranla daha kolay olması konusunda önemli avantajlar sunmaktadır.

Sosyal medyanın sivil organizasyonlara sağladığı faydalar şu şekilde sıralanmaktadır (Binark ve Löker, 2011, s.17):

- Öncelikle enformasyon temin eder.

- Üyeleri eyleme çağırmaya ve harekete geçirmeye yardımcı olur.

- Üyeler arasında etkileşim ve diyalog olanağı sunar.

- Farklı hareketlerde yer alan aktivistleri birbirine bağlar.

- Farklı STK'ları bağlar, bunlar arasında bağlantılar kurar.

- Örgütün üyelerine yaratıcı ifade olanakları ve zemini sağlar.

- Fon toplama ve kaynak yaratma olanağı sağlar.

Yapılan akademik çalışmalara bakıldığında sosyal medyanın STK'lar açısından kullanımına yönelik çeşitli çalışmaların yapıldığı görülmektedir (Seoa, Kim ve Yang, 2009; Waters ve arkadaşları, 2009; Curtis ve arkadaşları, 2010). Bu 
çalışmalarda sosyal medyanın STK'nın imajını desteklemek ve bağış kaynaklarını arttırmak konusunda bir işleve sahip olduğu, paydaşlarla sosyal ilişkiyi geliştirmek konusunda fayda sağladığına yönelik çeşitli sonuçlara ulaşılmıştır. Dolayısıyla STK'lara birçok açıdan yarar sağlayan bu ortamları doğru bir kurumsal kimlik temelinde kullanmak hem kullanıcılar hem de STK'lar açısından birçok faydayı beraberinde getirebileceği, bu anlamda yapılan çalışmaların yol gösterici nitelikte olabileceği bilinmelidir.

\section{Yöntem}

Çalışmanın amacı, sosyal medya ortamlarından biri olan Facebook'un STK'lar açısından kullanımını kurumsal kimlik temelinde ortaya çıkarmaktır. Çalışmadan elde edilen veriler STK'ların kendilerini Facebook'ta kimlikleri doğrultusunda daha iyi nasıl yansıtabilecekleri konusunda yönlendirici olacaktır. Yapılan araştırmada kurum kimliğinin unsurlarını oluşturan iletişim, tasarım, felsefe ve davranışın yanı sıra kurum kimliğini bütünsel bir açıdan değerlendirmek için etkileşimde olduğu alanlar olan kültür ve imaj boyutları da ele alınmıştır.

Çalışma özellikle sınırlı para kaynaklarından dolayı kendilerini geleneksel medya ortamlarında yeterince ifade edemeyen STK'ların sosyal medya ortamlarında kendilerini nasıl ifade ettiklerini göstermesi açısından önemlidir. Elde edilen sonuçlar STK'ların kurumsal kimliğini sosyal medya ortamı olarak Facebook'ta ne derece yansıttığını ortaya koyması ve kurumsal kimlik açısından eksikliklerini belirleyerek bu eksiklikleri nasıl tamamlayabileceği konusunda yol gösterici olacaktır. Ayrıca yapılan çalışmalar arasında sosyal medya ve STK'lara yönelik çeşitli çalışmaların bulunmasına rağmen STK'ların sosyal medya kullanımlarını kurumsal kimlik temelinde ele alan başka çalışmanın bulunmaması alana ve literatüre bu anlamda katkı sağlamaktadır. Bu doğrultuda aşağıdaki sorulara cevap aranmaya çalışılmıştır:

- Vakıf ve derneklerin kurumsal iletişim unsuru açısından Facebook kullanım oranı nedir?

- Vakıf ve derneklerin kurumsal tasarım unsuru açısından Facebook kullanım oranı nedir?

- Vakıf ve derneklerin kurumsal imaj unsuru açısından Facebook kullanım oranı nedir?

- Vakıf ve derneklerin kurumsal kültür unsuru açısından Facebook kullanım oranı nedir?

- Vakıf ve derneklerin kurumsal felsefe unsuru açısından Facebook kullanım oranı nedir?

- Vakıf ve derneklerin kurumsal davranış unsuru açısından Facebook kullanım oranı nedir?

Çalışma bazı sınırlııklar çerçevesinde ele alınmıştır. Buna göre çalışmada ilgili resmi kurumlardan alınan vakıf ve dernek listeleri temel alınmış, sendikalar çalışma kapsamı dışında bırakılmıştır. Sosyal medya ortamlarında kurumlara 
ait gayri resmi hesapların varlığından dolayı resmi sosyal medya hesaplarına ulaşabilmek için STK'ların kendi web siteleri temel alınmıştır. Ayrıca vakıf ve derneklerin merkez hesapları araştırmaya dâhil edilmiş bölge ya da şubelere yönelik hesaplar araştırmaya dâhil edilmemiştir. Bununla birlikte sosyal medya aracı olarak sadece Facebook üzerinden inceleme yapılmış, diğer sosyal medya araçları kapsam dışında bırakılmıştır. Araştırmadan elde edilen sonuçlar vakıf ve derneklerin 15 Şubat 2015-15 Şubat 2016 tarihleri arasındaki iletilerin içeriği ile sınırlıdır. Ölçmede kullanılan kurum kimliğine ait alt bileşenlerin kurum kimliğini yansıttığı kabul edilmiştir.

Çalışmada STK'ların Facebook'taki kurumsal kimliklerini yansıtma durumlarının ne olduğunu belirleyebilmek ve var olan durumunu ortaya koymak için betimleyici araştırma tasarımına yer verilmiştir. Betimleyici araştırma modelinde araştırmacılar gözlemlerini yaparak sonrasında gözlemledikleri şeyin ne olduğunu tanımlamaya çalışmaktadır. Burada var olan bir durumun ya da olgunun tanımlanması amaçlanmaktadır (Rubin ve Babbie, 2011, s.134). Erdoğan (2007), tanımlayıcı/betimleyici incelemelerin ilişkiler üzerinde durmadığını, hipotezleri test etmediğini, tahminlerde bulunmadığını belirterek değişkenlerin doğası hakkında bilgi verdiğini, benzer özelliklere göre gruplamalar yaptığını ifade etmiştir.

Çalışmada söz konusu durum saptamasını yapabilmek ve gerekli olan verileri elde edebilmek için içerik analizi yöntemi kullanılmıştır. Bu yöntemin kullanılmasının nedeni Facebook'ta kurumsal kimlik unsurlarının incelenen STK'lar arasında ne sıklıkla gözlemlendiğinin ortaya çıkarılmak istenmesidir. İçerik çözümlemesinde, kodlama yoluyla elde edilen veriler kategorilere ayrılır, bu kategoriler arasındaki ilişkiler ortaya çıkarılır ve buna dayalı olarak temalar ve alt-temalar saptanır. Kısaca, elde edilen veriler belirli temalara dayalı olarak bir araya getirilerek düzenlenir ve yorumlanır (Salı, 2013, s.127). Binark (2014), içerik çözümlemesinin temel amacını, bir metin içinde bulunan karakteristiklerin ne sıklıkla tekrar ettiğini, hangi tutumla sunulduğunu araştırmak ve mesajların biçimsel özelliklerini saptamak olarak belirtmiştir.

Çalışmada incelenecek olan vakıf ve dernekleri belirleyebilmek için resmi kanallardan Bilgi Edinme Kanunu çerçevesinde mail aracılığı ile liste talep edilmiştir. Gönderilen listede toplamda 656 tane vakıf ve dernek statüsüne sahip STK olduğu belirlenmiştir. İkinci aşamada ise; elde edilen listedeki vakıf ve derneklerin resmi Facebook hesaplarına ulaşabilmek için web sitelerine ulaşılmış ve 395 tanesinin bir web sitesine sahip olduğu saptanmıştır. Bunlar arasında ise sadece 178 tanesinin bir Facebook hesabı olduğu tespit edilmiştir. Bu nedenle çalışmanın analiz birimini bu 178 vakıf/dernek oluşturmaktadır.

Çalışmada yer alan araştırma sorularını cevaplayabilmek için bir kodlama listesine ihtiyaç duyulmuş, bu nedenle Okay (2003) ve Facebook'un kendi özellikleri doğrultusunda saptanan unsurlara göre bir kodlama listesi 
oluşturulmuştur. Kodlama cetvelinin oluşturulması sürecinde literatürdeki bilgiler ve araştırmalar temel alınmış ve formun geçerliliği konusunda uzman görüşüne başvurulmuştur. Kodlama listesinin ilk bölümünde temel bilgiler, ikinci kısımda ise kurum kimliği unsurları ve etkileşimde olduğu alanların yansımalarına yönelik bilgiler yer almaktadır.

Temel bilgilerin yer aldığı ilk bölümde, STK'ların faaliyette bulundukları alanlara göre sınıflandırmasını yapmak için kapsamlı olması açısından International Classification of Non-profit Organizations'ın ${ }^{3} 12$ ayrı kategorideki sınıflandırması temel alınmıştır. Vakıf ve dernekler uluslararası sınıflandırma kapsamında 12 kategoriye ayrımış ve web sitesi üzerinde sosyal medya aracı bulundurup bulundurmamalarına göre frekans analizi yapılarak incelenmiştir. Ayrıca bu bölümde STK'ların Facebook'taki aktiflik durumlarının belirlenmesi için paylaşımlarının günlük, haftalık ve aylık dağılımına, kullanıcılar tarafından hesapların beğenilme ve takipçi sayılarına bakılmıştır. Kodlama listesinin ikinci bölümünde ise, kurumsal kimlik unsurları ve etkileşimde olduğu alanlara yönelik veriler elde edilmeye çalışılmıştır.

Kurumsal kimlik unsurları, etkileşimde olduğu alanlar ve bunların alt bileşenlerinin neler olduğu belirlemek için Okay (2003)'te yer alan kurumsal kimliğin unsurları ve yansımalarına yönelik bilgiler temel alınmıştır. Okay (2003), kurum kimliğinin unsurlarını Kiessling ve Spannagl'ın (1996) sınıflandırması doğrultusunda ele almış, bu unsurların kurumsal felsefe, davranış, tasarım ve iletişimden oluştuğunu belirtmiştir. Kurum kimliğinin etkileşimde olduğu alanları ise; kurum kültürü ve kurum imajı olarak ifade etmiş, söz konusu unsurların iç ve dış ilişkilerdeki yansımasına yönelik bilgilere yer vermiştir.

Çalışmada incelenen STK'ların Facebook sayfalarından kurumsal kimlik unsurları ve etkileşimde olduğu alanlara yönelik veriler bu bilgiler temelinde toplanmış, ayrıca belirtilen unsurlara yönelik içeriklerin Facebook özelinde uyarlaması yapılmışıır. Kurum kimliğinin unsurlarına yönelik alt bileşenler ise şu şekildedir:

- Kurumsal kültür: kuruluş tarihçesi, örgüt kahramanları, geleneksel törenler ve değerler

- Kurumsal felsefe: vizyon, misyon, amaçlar ve slogan;

- Kurumsal davranış: yönetici konuşması, iki yönlü iletişimin varlığı, harekete geçirici çabalar, üyelerin içerik üretimi, bize katılın \& gönüllü olun, bağışta bulunma, ziyaretçi gönderileri, kurum satış malzemeleri yönlendirme;

- Kurumsal tasarım: logo, kurum içi yayınlar, çalışma ortamı;

- Kurumsal imaj: hakkında yorumlar, ödüller, gönderilerin beğenilmesi ve paylaşılması;

3 http://www.abs.gov.au/AUSSTATS/abs@.nsf/Lookup/5256.0.55.001Appendix5Jul+2010 ((Erişim Tarihi: 05.12.2017). 
Kurumsal iletişim: kurumun paylaştığı haberler, medyada çıkan haberler, basılı iletişim materyalleri, basın bültenleri, etkinlik duyurumu, web sayfası linki, adres paylaşımı, e-posta kullanımı, farklı sosyal medya aracı kullanımı, iletişim numarası paylaşımı, hashtag (etiket) kullanımı, mesaj gönderme uygulaması, abone olma, kampanya bilgisi paylaşımı, eğitim-seminer faaliyetleri, e-bülten kayıt formu, bizimle iletişime geç uygulaması, hakkında konuşanlar.

Çalışma için üç kodlayıcıdan yararlanılmış ve kodlama cetvelinde ortak bir dilin sağlanması amacıyla operasyonel tanım listesi hazırlanmıştır. Kodlayıcılar arasında tutarlıık olup olmadığını belirlemek amacıyla Kripperdorff geçerlilik ve güvenirlilik analizi yapıımış ve üç kodlayıcı için Kripperdorff katsayısı 0,86 olarak belirlenmiştir. Elde edilen değer Kripperdorff'un (2004) kabul edilebilir en düşük güvenirlilik değerinin (0.667) üzerindedir, bu nedenle kodlayıcılar arasındaki tutarlılık kabul edilebilir düzeydedir.

\section{Bulgular}

Vakıf ve derneklerin sosyal medya ortamı olarak kurumsal kimlik temelinde Facebook kullanımı ile ilgili bilgiler aşağıda tablolar halinde gösterilmektedir.

Tablo 1. Vakıf ve derneklerin Facebook hesaplarının genel durumu

\begin{tabular}{|l|l|l|}
\hline & STK & $\%$ \\
\hline Aktif & 120 & $\% 87,4$ \\
\hline Sayfa açılmıyor & 23 & $\% 12,9$ \\
\hline Aktif değil & 15 & $\% 8,4$ \\
\hline Grup / kişi sayfası & 12 & $\% 6,7$ \\
\hline Beğenmeye / paylaşmaya yönlendirme & 8 & $\% 4,5$ \\
\hline Toplam & $\mathbf{1 7 8}$ & \% $\mathbf{1 0 0}$ \\
\hline
\end{tabular}

Yapılan çalışmalar sonucunda kurumsal web siteleri üzerinden resmi hesaplarına ulaşılan toplamda 395 vakıf ve derneğin yalnızca 178 tanesinin Facebook hesabının olduğu belirlenmiştir. Bunlardan büyük çoğunluğunun $(\% 67,4)$ Facebook hesabını aktif olarak kullandığı; \%8,4'ünün ise web sayfaları üzerinden Facebook hesaplarına yönlendirmede bulunmasına rağmen sayfayı aktif kullanmadıkları görülmüştür. Facebook'u kullanan vakıf ve derneklerin $\% 12,9$ 'unun web sitelerinde yönlendirdikleri sayfaların/linklerin açımadığı, $\% 6,7$ 'si kurumsal bir hesap kullanmak yerine grup-kişi sayfaları oluşturma yönünde bir eğilim gösterdiği belirlenmiştir. Vakıf ve derneklerin \%4,5'inin ise söz konusu sayfayı kendi hesabınızda beğenme/paylaşmaya yönlendirdiği görülmektedir. Dolayısıyla çalışmanın bundan sonraki kısmında elde edilen veriler Facebook'u aktif olarak kullanan 120 vakıf/dernek temelinde ele alınmıştır. 
Tablo 2. STK Sınıflandırmalarına göre Facebook kullanımı

\begin{tabular}{|l|l|l|}
\hline & STK & $\%$ \\
\hline Sosyal hizmetler & 23 & $\% 19,2$ \\
\hline Eğitim ve araştırma & 22 & $\% 18,3$ \\
\hline Sağlık & 18 & $\% 15$ \\
\hline İş örgütleri, mesleki örgütler ve sendikalar vb. & 15 & $\% 12,5$ \\
\hline Dini & 10 & $\% 8,3$ \\
\hline Kültür ve eğlence & 7 & $\% 5,8$ \\
\hline İilikseverlik aracıları ve gönüllü teşvikçileri & 6 & $\% 5$ \\
\hline Çevre & 5 & $\% 4,2$ \\
\hline Hukuk, savunuculuk ve politika & 3 & $\% 2,5$ \\
\hline Uluslararası & 3 & $\% 2,5$ \\
\hline Kalkınma ve barınma & 2 & $\% 1,7$ \\
\hline Diğerleri & 6 & $\% 5$ \\
\hline Toplam & $\mathbf{1 2 0}$ & $\% \mathbf{1 0 0}$ \\
\hline
\end{tabular}

Vakıf ve dernek sınıflandırmaları açısından Facebook'taki aktiflik durumuna bakıldığında, Facebook'ta ilk sırada \%19,2 ile sosyal hizmetler kategorisi yer alırken, eğitim ve araştırma kategorisi \% 18,3 ile ikinci sırada; sağlık ise üçüncü sırada yer almaktadır. Facebook hesabını aktif olarak kullanımda kalkınma ve barınma kategorisi \% 1,7'ile en son sırada yer almaktadır.

Tablo 3. Vakıf ve dernek sayfalarının kişiler tarafından beğenme sayılarının dağılımı

\begin{tabular}{|l|l|l|}
\hline Kişi sayısı & STK & $\%$ \\
\hline $1-5.000$ & 54 & $\% 45$ \\
\hline $5.001-25.000$ & 34 & $\% 28,3$ \\
\hline $25.001-125000$ & 14 & $\% 11,7$ \\
\hline 125.001 ve üzeri & 18 & $\% 15$ \\
\hline Toplam & $\mathbf{1 2 0}$ & $\% \mathbf{1 0 0}$ \\
\hline
\end{tabular}

Facebook'ta aktif olarak bulunan vakıf ve derneklerin resmi hesaplarının kişiler tarafından beğenilme oranlarına bakıldığında \%45'ini beğenen kişi sayısı 1-5000 arasında iken \%28,3'ünün 5001-25.000 arasında beğenen kişi sayısı bulunmaktadır. Sayfayı beğeni sayısının 25.001-125.000 arasında olduğu vakıf ve derneklerin oranı \%11,7 iken en fazla (125.001 ve üzeri) beğeni sayısına sahip vakıf ve derneklerin oranı ise \%15 olarak belirlenmiştir. Sosyal medyada kullanıcılar tarafından toplamda 1.663,275 kişi tarafından en beğenilen vakıf/ derneğin "uluslararası" kategorisinde olduğu belirlenmiş̦tir. Bununla birlikte en fazla beğenme sayısına sahip diğer vakıf ve derneklerin sırasıyla 672.672 beğenme ile "iyilikseverlik aracıları ve gönüllü teşvikçileri"; 593.140 beğenme ile sağlık kategorilerinde yer aldığı saptanmıştır. 
Tablo 4: Vakıf ve dernek sayfalarının kullanıcılar tarafından değerlendirmesi

\begin{tabular}{|l|l|l|}
\hline Değerlendirmeler & STK & $\%$ \\
\hline Değerlendirme yapılmamış & 46 & $\% 38,3$ \\
\hline $3,5-3,9$ & 5 & $\% 4,2$ \\
\hline $4,0-4,4$ & 9 & $\% 7,5$ \\
\hline $4,5-4,9$ & 48 & $\% 40$ \\
\hline 5,0 & 12 & $\% 10$ \\
\hline Toplam & $\mathbf{1 2 0}$ & $\% \mathbf{1 0 0}$ \\
\hline
\end{tabular}

Facebook kullanıcılarına sayfaların değerlendirme yapabilmesine yönelik olarak bir uygulama sunmaktadır. Bu sayede takipçilerin sayfa hakkındaki görüşlerine yönelik genel bir değerlendirme yapılabilmesi mümkündür. Vakıf ve derneklerin takipçileri tarafından sayfalarına verilen değerlendirme puanlamalarına bakıldığında; \%10'unun takipçileri tarafından 5,0 tam puan üzerinden değerlendirildiği görülmektedir. Bununla birlikte değerlendirme sonucunda 4,54,9 arasında bir puanlamaya sahip olan vakıf ve derneklerin oranı \%40 iken; kendi sayfasında "değerlendirme" uygulamasını kullanmayıp kullanıcılarının sayfaları hakkında herhangi bir değerlendirme yapmalarına izin vermeyenlerin oranı ise \%38,3 olarak belirlenmiştir.

Tablo 5. Gönderi paylaşımına yönelik dağılımı

\begin{tabular}{|c|c|c|c|}
\hline 1 gün & STK & $\%$ & Toplam gönderi sayısı \\
\hline $\begin{array}{l}0 \text { gönderi } \\
1 \text { gönderi } \\
2 \text { gönderi } \\
3 \text { gönderi } \\
4 \text { gönderi } \\
5+\text { gönderi }\end{array}$ & $\begin{array}{l}59 \\
45 \\
8 \\
5 \\
2 \\
1\end{array}$ & $\begin{array}{ll}\% & 49,2 \\
\% & 37,7 \\
\% & 6,7 \\
\% & 4,2 \\
\% & 1,7 \\
\% & 0,8\end{array}$ & 89 gönderi \\
\hline \multicolumn{4}{|l|}{1 ay } \\
\hline $\begin{array}{l}\text { Hiç gönderi yok } \\
1-10 \text { gönderi } \\
11-20 \text { gönderi } \\
21-30 \text { gönderi } \\
31-40 \text { gönderi } \\
41-50 \text { gönderi } \\
51+\end{array}$ & $\begin{array}{l}9 \\
35 \\
28 \\
27 \\
6 \\
7 \\
8\end{array}$ & $\begin{array}{l}\% 7,5 \\
\% 29,2 \\
\% 23,3 \\
\% 22,5 \\
\% 5 \\
\% 5,8 \\
\% 6,7\end{array}$ & 2552 gönderi \\
\hline \multicolumn{4}{|l|}{2 ay } \\
\hline $\begin{array}{l}\text { Hiç paylaşım yok } \\
\text { 1-15 gönderi } \\
\text { 16-30 gönderi } \\
\text { 31-45 gönderi } \\
\text { 46-60 gönderi } \\
61-75 \text { gönderi } \\
76+\end{array}$ & $\begin{array}{l}3 \\
35 \\
17 \\
22 \\
15 \\
12 \\
16\end{array}$ & $\begin{array}{ll}\% & 2,5 \\
\% & 29,2 \\
\% & 14,2 \\
\% & 18,3 \\
\% & 12,5 \\
\% & 10 \\
\% & 13,3\end{array}$ & 5212 gönderi \\
\hline
\end{tabular}


Tabloda görüldüğü gibi vakıf ve dernekler bir gün içinde toplamda 89 gönderi paylaşmıştır. Vakıf ve derneklerin \%49,2'si gün içerisinde herhangi bir gönderi paylaşımında bulunmazken, \%37,5'i sadece 1 gönderi paylaşmıştır. Bir gün içerisinde en fazla olan 5 gönderi paylaşımında sadece 1 vakıf/derneğin olduğu görülmektedir. Facebook'ta vakıf ve dernekler arasında bir gün içinde 5 tane $(\% 0,8)$ olmak üzere en fazla gönderi paylaşımı "Eğitim ve Araştırma" kategorisinde bulunan bir vakıf/dernek tarafından yapılmıştır. "İilikseverlik aracıları ve gönüllü teşvikçileri" ile "din" kategorilerinde bulunan 2 vakıf/dernek ise gün içinde 4 gönderi paylaşımında bulunarak en fazla paylaşım yapan vakıf ve dernek kategorileri arasında ikinci sırada yer almaktadır.

Vakıf ve derneklerin 1 aylık süreç içerisindeki gönderi paylaşımına bakıldığında ise toplamda 2552 gönderinin paylaşıldığı görülmektedir. Vakıf ve derneklerin \%29,2'si bir ay içinde toplamda 1-10 arasında bir gönderi paylaşımında bulunurken \%6,7'si ise aylık 51+ gönderi paylaşımında bulunmuştur. Bununla birlikte 1 aylık süreç içerisinde hiç paylaşımda bulunmayanların oranı ise $\% 7,5$ olarak belirlenmiştir. Facebook'ta bir ay içinde en fazla gönderi paylaşımı sırasıyla; 179 gönderi ile "iyilikseverlik aracıları ve gönüllü teşvikçileri"; 142 gönderi paylaşımı ile "din" ve 59 gönderi ile "çevre" kategorisinde bulunan bir vakıf/ dernek tarafından yapılmıştır.

Araştırmanın yapıldığı 15 Aralık- 15 Şubat tarihleri arasında vakıf ve dernekler Facebook'ta toplamda 5212 gönderi paylaşmışlardır. Bu gönderi paylaşımlarında 1-15 gönderi arasında paylaşım yapanların oranı \%29,2 iken \%18,3'ü 31-45 gönderi arasında paylaşımda bulunmuştur. Bununla birlikle iki aylık süreç içerisinde 76+ 'dan dan fazla gönderi paylaşanların oranı \% 13,3 olarak belirlenmiştir. Facebook'ta en fazla (76+) gönderi paylaşımı sırasıyla "iyilikseverlik aracıları ve gönüllü teşvikçileri" (300 gönderi), "din" (236 gönderi), "kültür ve eğlence" (135 gönderi) kategorilerinde bulunan bir vakıf/dernek tarafından yapılmıştır.

\section{Facebook'ta Kurumsal Kimlik Unsurlarına Yönelik Bulgular}

Bu bölümden elde edilen sonuçlar vakıf ve derneklerin kurumsal kimlik temelinde yer alan unsurları ne kadar kullandıklarını ortaya çıkaracaktır.

Tablo 6: Kurumsal kültür bileşenlerinin dağılımı

\begin{tabular}{|l|l|l|}
\hline Bileşen & STK Sayısı & $\%$ \\
\hline Kuruluş tarihçesi & 44 & $\% 36,7$ \\
\hline Geleneksel törenler & 36 & $\% 30,0$ \\
\hline Örgüt kahramanları & 18 & $\% 15,0$ \\
\hline Değerler & 3 & $\% 2,5$ \\
\hline
\end{tabular}


Facebook'ta kurum ya da kişilerin kendileri hakkında bilgi verdikleri alan "hakkında" başlığıaltındayeralmaktadır. Incelenenvakıfve derneklerin \% 100'ünde hakkında kısmının yer aldığı saptanmıştır. Araştırma kapsamına dâhil edilen vakıf ve derneklerin sayfalarında kurumsal kültür unsurlarını yansımasına bakıldığında 44 tanesinin $(\% 36,7)$ kuruluş tarihçesine yer verdiği, 36 tanesinin $(\% 30,0)$ ise geleneksel törenlerini ifade eden içeriklerinin bulunduğu belirlenmiştir. 18 tanesi (\%15) ise örgüt kahramanlarına yönelik bilgilerini sayfalarında paylaşmıştır. Vakıf ve dernekler arasında kurumsal kültüre yönelik olarak en az bilgi paylaşımı değerler bileşenine aittir. Sosyal medya hesabı üzerinden değerlerini belirten vakıf ve derneklerin sayısı sadece 3 tane $(\% 2,5)^{\prime}$ dir.

Vakıf ve derneklerin 45 tanesi $(\% 37,5)$ kurum kültürü bileşenlerinden hiçbirine sayfalarında yer vermezken büyük bir kısmı $(\% 42,5)$ bu bileşenlerden sadece birine yer vermektedir. Kurum kültürü bileşenlerinden hepsine yönelik bilgilere sayfalarında yer veren vakıf ve derneğe rastlanılmamıştır.

Tablo 7. Kurumsal felsefe bileşenlerinin dağılımı

\begin{tabular}{|l|l|l|}
\hline Bileşen & STK Sayısı & $\%$ \\
\hline Amaçlar & 67 & $\% 55,8$ \\
\hline Misyon & 65 & $\% 54,2$ \\
\hline Slogan & 26 & $\% 21,7$ \\
\hline Vizyon & 12 & $\% 10$ \\
\hline
\end{tabular}

Facebook'taki sayfalarında amaçlarını paylaşan vakıf ve derneklerin sayısı 67 $(\% 55,8)$ iken misyonunu paylaşanların sayısının $65(\% 54,2)$ olduğu belirlenmiştir. Bununla birlikte vakıf ve derneklerin 26 'sı $(\% 21,7)$ sayfalarında sloganlarına yer verirken, 12'si (\%10) ise vizyonlarını açık bir şekilde belirtmişlerdir. Vakıf ve derneklerin sayfalarında en az yansıttıkları bileşenin vizyon olduğu görülmektedir. Inceleme alınan vakıf ve derneklerin 21 tanesi $(\% 17,5)$ kurumsal felsefe altında yer alan 4 bileşenden hiçbirine sayfalarında yer vermezken, büyük bir çoğunluğunun $(\% 36,7)$ iki tanesine verdiği belirlenmiştir. Vakıf ve derneklerin sadece 1 tanesi $(\% 0,8)$ kurum felsefesi bileşenlerinden hepsine sayfalarında yer vermektedir.

Tablo 8. Kurumsal tasarım bileşenlerinin dağılımı

\begin{tabular}{|l|l|l|}
\hline Bileşen & STK Sayısı & $\%$ \\
\hline Logo & 119 & $\% 99,2$ \\
\hline Kurumiçi yayınlar & 65 & $\% 54,2$ \\
\hline Çalışma ortamı & 31 & $\% 25,8$ \\
\hline
\end{tabular}

Vakıf ve derneklerin tamamına yakınının $(\% 99,2)$ sayfalarında kurumsal tasarım bileşenlerinden biri olan logo kullanımına yer verdiği; logo kullanmayan sadece bir tane STK'nın olduğu saptanmıştır. Kurumiçi yayınların kullanımına bakıldığında ise vakıf ve derneklerin yarısından fazlasının $(\% 54,2)$ Facebook 
üzerinden kurumiçi yayınlarına yönelik materyalleri paylaştıkları görülmektedir. Analiz kapsamında yer alan vakıf ve derneklerin sadece \%25,8'sinin çalışma ortamı/ teçhizatına yönelik paylaşımlarda bulunduğu tespit edilmiştir. Vakıf ve derneklerin 1 tanesi $(\% 0,8)$ kurumsal tasarım bileşenlerinden hiçbirini kullanmazken, büyük bir çoğunluğu $(\% 42,5)$ bu bileşenlerden sadece bir tanesine; 28 tanesi $(\% 23,3)$ ise kurumsal tasarım bileşenlerinden hepsine yönelik bilgilerine sayfalarında yer vermektedir.

Tablo 9. Kurumsal davranış bileşenlerinin dağılımı

\begin{tabular}{|l|l|l|}
\hline Bileşen & STK Sayısı & $\%$ \\
\hline İki yönlü iletişimin varlığı & 57 & $\% 47,5$ \\
\hline Harekete geçirici çabalar & 55 & $\% 45,8$ \\
\hline Ziyaretçi gönderileri & 47 & $\% 39,2$ \\
\hline Üyelerin içerik üretimi & 44 & $\% 36,7$ \\
\hline Yönetici konuşması & 35 & $\% 29,2$ \\
\hline Bağışta bulunun & 31 & $\% 25,8$ \\
\hline Kurum satış malzeme yönlendirme & 25 & $\% 20,8$ \\
\hline Bize katıın \& Gönüllü olun & 14 & $\% 11,7$ \\
\hline
\end{tabular}

Vakıf ve derneklere yönelik olarak kurumsal davranış unsurlarının dağııımına yönelik yapılan analizden elde edilen bulgular yukarıdaki tabloda gösterilmiştir. Buna göre, vakıf ve derneklerin yaklaşık yarısı $(\% 47,5)$ iki yönlü iletişim ve harekete geçirici çabalara $(\% 45,8)$ yer vermektedir. Vakıf ve derneklerin sayfalarını beğenen kişiler tarafından kuruma yönelik yaptığı yorumları (ziyaretçi gönderileri) sayfada paylaşanların oranı \%39,2 oranında kalırken vakıf ve derneklerin büyük bir kısmının yapılan yorumları yayınlamadığı görülmektedir. Vakıf ve derneklerin büyük bir kısmının kullanıcıların sayfalarında paylaşım yapmasına izin vermedikleri görülmektedir. Takipçilerinin herhangi bir şekilde paylaşım yapmasına izin verenlerin oranı \%36,7 olarak belirlenmiştir. Bununla birlikte vakıf ve derneklerin büyük bir çoğunluğu sayfalarında herhangi bir yönetici konuşmasına yer vermediği sadece \%29,2'inin buna yönelik paylaşımlarda bulunduğu saptanmıştır.

Vakıf ve derneklerin önemli gelir kaynaklarından biri olan kuruma bağışta bulunulmasına yönelik paylaşımlarda bulunanların oranı \%25,8 iken kurumun kazanç sağlamasını elde edecek uygulamalardan biri olan satış malzeme yönlendirmesi uygulamasını kullananların oranı \%20,8'de kalmıştır. Sosyal medya ortamları benzer düşünce yapısına sahip insanların kolayca biraraya gelebileceği ortamlardan biridir ve bu ortamlar bu nedenle özellikle STK için gönüllü sağlama, çalışmalarına destek verebilecek kişilere ulaşabilme konusunda büyük avantajlar sunmaktadır. Ancak incelenen vakıf ve derneklerin takipçileri gönüllü olmaya teşvik etmeye yöneltecek herhangi bir çabada bulunmadığı, sadece \%11,7'sinin takipçileri gönüllü olmaya teşvik edecek paylaşımlarda bulunduğu görülmüştür. 
Vakıf ve derneklerin 19 tanesi $(\% 15,8)$ kurumsal davranış altında yer alan bileşenlerinden hiçbirini kullanmazken büyük bir kısmı $(\% 54,2)$ bu bileşenlerin 1 ile 3 tanesine yer vermektedir. Vakıf ve derneklerden sadece 4 tanesi $(\% 3,3)$ kurumsal davranış bileşenlerinden 7 tanesini kullanırken; kurumsal davranış bileşenlerinden hepsini kullanan vakıf ve derneğe rastlanmamıştır.

Tablo 10. Kurumsal iletişim bileşenlerinin dağılımı

\begin{tabular}{|l|l|l|}
\hline Bileşen & STK Sayısı & $\%$ \\
\hline Web sayfası linki & 119 & $\% 99,2$ \\
\hline Hakkında konuşanlar & 119 & $\% 99,2$ \\
\hline İletişim numaraları & 110 & $\% 91,7$ \\
\hline Kurum haberleri & 110 & $\% 91,7$ \\
\hline E-posta & 100 & $\% 83,3$ \\
\hline Adres & 99 & $\% 82,5$ \\
\hline Basılı iletişim materyalleri & 83 & $\% 69,2$ \\
\hline Abone ol & 81 & $\% 67,5$ \\
\hline Etkinlikler & 74 & $\% 61,7$ \\
\hline Medyada çıkan haberler & 66 & $\% 55,0$ \\
\hline Etiket (Hastagh) & 56 & $\% 46,7$ \\
\hline Kampanya bilgisi & 47 & $\% 39,2$ \\
\hline Farklı sosyal medya araçları kullanımı & 46 & $\% 38,3$ \\
\hline Eğitim-Seminer bilgisi & 45 & $\% 37,5$ \\
\hline Bizimle iletişime geç & 36 & $\% 30$ \\
\hline Şimdi mesaj gönder & 27 & $\% 22,5$ \\
\hline Basın bültenleri & 15 & $\% 12,5$ \\
\hline E-bülten kayıt formu & 5 & \\
\hline
\end{tabular}

Vakıf ve derneklerin Facebook hesaplarında hemen hemen hepsinde kurumsal web sayfasına yönlendirecek linklerin kullanıldığı görülmektedir. Kurumsal iletişime yönelik olarak sayfalarında iletişim numaralarını paylaşanların oranı \%91,7 iken e-posta $(83,3)$ ve adres bilgilerini paylaşanların oranının $\% 82,5$ olduğu belirlenmiştir.

Vakıf ve derneklerin sayfalarında yoğunlukla kurumları ile ilgili haberleri takipçileri ile paylaştıkları ve onları bilgilendirmeye yönelik paylaşımlarda bulundukları görülmektedir. Bununla birlikte vakıf ve derneklerin yarısından fazlasının yaptıkları/yapacakları etkinliklerle ilgili bilgilere yer verirken medyada çıkan haberleri de bu ortamlarda paylaşmaya özen gösterdikleri görülmektedir. Vakıf ve dernekler arasında bir kısmının paylaşımlarında etiketlere (hastagh) yer vermekte ve farklı sosyal medya araçlarını da entegre bir şekilde kullanmaya çalışmaktadır. Facebook'ta en az paylaşılan kurumsal iletişim bileşenlerinin basın bültenleri $(\% 12,5)$ ve kurum hakkında anında bilgi almaya yönelik bir uygulama olan e-bülten kayıt formu $(\% 4,2)$ olduğu görülmektedir. 
Incelenen vakıf ve derneklerin büyük bir kısmı (\%50) toplamda 18 tane olan kurumsal iletişim bileşenlerinden 11-15 tanesini kullanırken kurumsal iletişim bileşenlerinden hepsini kullanan vakıf ve derneğe rastlanılmamıştır.

Tablo 11. Kurumsal imaj bileşenlerinin dağılımı

\begin{tabular}{|l|l|l|}
\hline Bileşen & STK Sayısı & $\%$ \\
\hline Gönderilerin beğenilmesi & 116 & $\% 96,7$ \\
\hline Gönderilerin paylaşılması & 113 & $\% 94,2$ \\
\hline Nötr yorumlar & 97 & $\% 80,8$ \\
\hline İlgisiz yorumlar & 74 & $\% 61,7$ \\
\hline Pozitif yorumlar & 73 & $\% 60,8$ \\
\hline Açılmayan yorumlar & 60 & $\% 50$ \\
\hline Negatif yorumlar & 42 & $\% 35$ \\
\hline Ödüller & 20 & $\% 6,7$ \\
\hline
\end{tabular}

Kurum tarafından yapılan paylaşımların \%96,7 oranında sayfada yer alan diğer kişiler tarafından beğenildiği ayrıca vakıf ve derneklerin \%94,2'sinin gönderilerinin diğer kişiler tarafından kendi sayfalarında paylaşılığı tespit edilmiştir. Vakıf ve derneklere yönelik imajın oluşumunda sayfalarda yapılan yorumların niteliği büyük önem taşımaktadır. Incelenen vakıf ve derneklerin sayfalarında yapılan yorumların büyük bir çoğunluğu $(\% 80,8)$ kurum hakkında değil sadece gönderiye yönelik olarak yapılan nötr yorumlar şeklindedir. Vakıf ve derneklerin \%60,8'inin sayfalarında kuruma yönelik pozitif yorumlara rastlanırken $\% 35$ 'i hakkında negatif yönde yapılan yorumların var olduğu; \%50'sinin ise sayfalarında yer alan yorumları filtrelediği saptanmıştır. Vakıf ve derneklerin büyük bir kısmının aldığı ödüllere yönelik herhangi bir paylaşımda bulunmazken sadece $\% 16,7$ 'sinin ödüllerine yönelik bilgileri içeren paylaşımda bulunmuştur. Vakıf ve derneklerin 3 tanesi $(\% 2,5)$ kurumsal imaj bileşenlerinden hiçbirini kullanmazken büyük bir çoğunluğunun $(\% 51,7)$ bu bileşenlerden 4 ile 6 tanesine sayfalarında yer vermektedir. Kurumsal imaj bileşenlerinden hepsini kullanan vakıf ve derneğe rastlanılmamıştır.

\section{Sonuç ve Öneriler}

Bu çalışma kurumların varlığı, neyi nasıl yaptıkları konusunda bilgiler veren ve hedef kitlelerine kendisini tanıtan bir araç olarak karşımıza çıkan kurumsal kimliğin STK'lar tarafından sosyal medya ortamlarından biri olan Facebook'ta nasıl yansıtıldığını ortaya koymayı hedeflemiştir. Devereux vd. (2017) sosyal medyanın kurumların kimliklerini oluşturup geliştirmeleri için yeni bir yol ortaya çıkardığını ve yeni teknolojilerin kurumsal kimliğin ön plana çıkmasına katkıda bulunduğunu belirtmektedir. Bu nedenle STK'lar sadece sosyal medya hesabı açmakla yetinmeyip bu ortamlarda kendilerini nasıl daha iyi ifade edebileceklerini belirlemeli ve Facebook'u kurumsal kimliğini destekleyecek nitelikte işlevsel bir araç olarak kullanmalıdır. 
Çalışmada incelenen STK'ların Facebook'ta kurumsal kimlik açısından özellikle kurumsal iletişim ve tasarım unsurlarını yansıttıkları görülmüştür. Elde edilen bu sonuç Krake (2014) tarafından yapılan çalışmayla paralellik göstermektedir. STK'ların tamamına yakını Facebook hesaplarında logolarını ve büyük bir kısmı kurumiçi yayınlarını paylaşmaktadır. Kurumsal iletişim açısından bakıldığında ise hedef kitlelerin kendileriyle iletişime geçebilecekleri tüm unsurlara (web sayfası, telefon, adres, e-posta) hesaplarında yer verdikleri bazılarının ise çeşitli uygulamaları bu açıdan kullandığı belirlenmiştir. Facebook'ta kurumsal kimlik unsurlarından kurumsal davranış ve felsefeye yönelik içeriklerin ise daha az yansıtılan unsurlar arasında yer aldığı belirlenmiştir. Bu nedenle STK'lar kurumsal kimliğin sadece bu iki unsurdan ibaret olmadığını bilmeli ve kurum kimliğinin diğer unsurları olan kurumsal davranış ve felsefeyi de hesaplarında yansıtmaya önem vermelidir.

Kurumsal davranış kurumların hedef kitleleriyle karşı karşıya kaldığında ne şekilde davranmalarını gerektiğini belirleyen bu anlamda diğerlerinden fark edilmesini sağlamasına imkân veren bir unsurdur. STK'ların Facebook'ta hedef kitlelerine yönelik davranışları, kendilerini ifade ediş biçimleri onların imajı üzerinde etkili olmaktadır. Seo, Kim ve Yang (2009) STK'ların yeni medyayı kullanmasının kurum imajını sağlama ve bağış kaynaklarını artırma konusunda önemli iki işleve sahip olduğunu belirtmişlerdir. Dolayısıyla STK'lar bu ortamların kendilerine sundukları avantajları değerlendirmelidir. Waters vd. ise 2009 yılında yapılan çalışmada STK'ların Facebook'ta farkındalığı artıımak ya da katıımı teşvik etmek konusunda yetersiz olduğunu belirtmiştir. Bu çalışmada da STK'ların paylaşımlarında en az görülen kurumsal davranış bileşenlerinden birinin gönüllü olmaya yönelik içeriklerin olması benzer bir sonucu ortaya çıkarmıştır. Sosyal medya ortamlarının paydaşlara ulaşmada en hızlı ve düşük maliyetli araçlar olmasına rağmen incelenen STK'ların sadece bir kısmının iki yönlü iletişime izin vermesi bu ortamlarda hala simetrik bir iletişim yapısının yeterince oluşmadığı, STK'ların bu ortamları sadece bilgilendirme amacıyla kullandıklarının bir kanıtı olarak görülebilir.

Çalışmada kurumsal kimliği bir bütün içinde ele almak için kurumsal kimliğin etkileşim alanları olan kurum kültürü ve imaj unsurları da incelenmiştir. Kurumsal kimliğin etkileşimde olduğu unsurlardan biri olan kurumsal kültürün Facebook'ta yansımasına bakıldığında; STK'ların bu unsura yönelik bileşenlere hesaplarında çok fazla yer vermedikleri belirlenmiştir. Kurumsal kültür açısından en fazla yansıtılan bileşenin kuruluşun tarihçesiyle ilgili olduğu; değerlerin paylaşımının ise en az rastlanılan bileşen olduğu belirlenmiştir. Facebook kullanıcılarına ve kurumlara "hakkında" başığı altında kendilerini ifade edecekleri bir alan sunmakta ve bu alanda herhangi bir kısıtlamaya (sözcük, yazı uzunluğu vb.) gitmemektedir. Ancak çalışmadan elde edilen bulgularda vakıf ve derneklerin kurumsal kültür bileşenlerine yönelik detaylı bilgileri paylaşacakları bu alanı yeterince etkili kullanmadıkları görülmektedir. Bu nedenle STK'ların kendilerini rahat ifade edebilecekleri bu alanları etkili kullanmaları, kendilerini tanıtma aracı 
olarak bu alanları kullanmaları önemlidir. Kurumsal imaj açısından bakıldığında ise STK'ların büyük bir kısmının paylaşımlarının kullanıcılar tarafından beğenildiği ve kendi sayfalarında paylaşıldığı belirlenmiştir. Bu durum STK'ların kullanıcılarla etkileşime geçebildiğinin bir göstergesi sayılabilir.

Bu çalışmada sosyal medya platformu olarak Facebook seçilmiş ve elde edilen sonuçlar paylaşılmıştır. Dolayısıyla farklı platformlara yönelik olarak çalışmaların yapılması STK'ların kendilerini bu yeni ortamda nasıl yansıtmaları gerektiğini göstermesi açısından önem arz etmektedir. Çalışma sadece vakıf ve dernekler temelinde ele alınmıştır. STK denilince akla gelen bir diğer grup sendikalardır. Bu nedenle sendikalar üzerinde benzer şekilde bir çalışma yapılarak sonuçların değerlendirilmesi mümkündür. STK'ların sosyal medyadaki resmi hesaplarının takipçiler üzerindeki etki ve algısına yönelik daha kapsamlı bir çalışma bu doğrultuda ilerleyen zamanlarda gerçekleştirilebilir. Bununla birlikte çalışmanın yöntemi değiştirilerek STK'larda sosyal medyayı yöneten kişilerin bu anlamdaki görüşlerine yönelik çalışmalarda bulunulabilir.

\section{Kaynakça}

Aktuğlu, I. K. (2004). Marka Yönetimi: Güçlü ve Başarılı Markalar için Temel Ilkeler (2. baskı). İstanbul: İletişim Yayınları.

Argenti,P. ve Forman, J. (2002). The Power of Corporate Communication. NewYork: McGraw Hill.

Belasen, A.T. (2008). The Theory and Practice of Corporate Communication- A Competing Values Perspective. USA: Sage Publications.

Binark, M. ve Löker, K. (2011). Sivil Toplum Örgütleri için Bilişim Rehberi. Ankara.

Binark, M. (2014). Yeni Medya Çalışmalarında Araştırma Yöntem ve Teknikleri. Istanbul: Ayrıntı Yayınları.

Botha, E.; Farshid, M. ve Pitt, L. (2011). How Sociable? An Exploratory Study of University, Brand Visibility in Social Media. South African Journal of Business Management, 42(2), 43-51.

Curtis, L.; Edwards, C.; Fraser, K. L.; Gudelsky, S.; Holmquist, J.; Thornton, K. ve Sweetser, K.D. (2010). Adoption of Social Media for Public Relations by Nonprofit Organizations. Public Relations Review, (36), 90-92.

Derin, N. ve Demirel, E. T. (2010). Kurum İmajının Kurum Kimliği Açısından Açıklanabilirliği: İnönü Üniversitesi Turgut Özal Tıp Merkezi Örneği. Hacettepe Sağlık ldaresi Dergisi, 13(2), 155-193.

Devereux, L., Melewar, T. C. ve Foroudi, P. (2017). Corporate Identity and Social Media: Existence and Extension of the Organization. International Studies of Management \& Organization, 47(2), 110-134. 
Erdoğan, I. (2007). Pozitivist Metodoloji: Bilimsel Araştırma Tasarımı, Istatistiksel Yöntemler, Analiz ve Yorum (2.baskı). Ankara: Erk Yayınları.

Fombrun, C.J. (1996). Reputation: Realizing Value from the Corporate Image. Harvard Business School Press, Boston.

Gianfiglio, F. (2015). Corporate Identity Management on Social Media: An Analysis of Airline Companies' Representation of Their Corporate Identity Through YouTube Content. Erasmus University Rotterdam, Master Thesis.

Goffee, R. ve Gareth, J.(2002). Kurum Kültürü. (Çev.: Kıvanç Kutmandu). MediaCat: Ankara.

Karademir, T. ve Alper, A. (2011). Öğrenme Ortamı Olarak Sosyal Ağlarda Bulunması Gereken Standartlar (Standarts of Social Networks Beıng a Learnıng Environment). 5th International Computer \& Instructional Technologies Symposium, 22-24 September 2011 Firat University, Elazığ- Turkey.

Kietzmann, J. H.; Hermkens, K.; McCarthy, I. P. ve Silvestre, B. S. (2011). Social Media? Get Serious! Understanding the Functional Building Blocks of Social Media. Business Horizons, 54(3), 241-251.

Kiriakidou, O. ve Millward, L.J. (1999). Corporate Identity: External Reality or Internal Fit. International Centre for Corporate Identity Studies Working Paper Series, University of Strathclyde.

Krake, I. P. (2014). Corporate visual identity (CVI) on social media: Exploring the effects of consistent CVI - Yükseklisans Tezi- University of Twente).

Krippendorf, K. (2004). Content Analysis: An Introduction to Its Methodolgy. (Second Ed.). United Kingdom: Sage Publications.

Kostamo, U. (2013). The New Era of Corporate Marketing: Building and Managing Corporate Identity in Social Media. Yayınlanmamış Yüksek Lisans Tezi. Finlandiya: Aalto University.

Kuvykaite, R.ve Piligrimiene, Z. (2013). Communication in Social Media for Company's Image Formation. Economics and Management, 18(2), 305-317.

Lovejoy, K. ve Saxton G. D. (2012). Information, Community, and Action: How Nonprofit Organizations Use Social Media. Journal of Computer-Mediated Communication, (17), 337-353.

Melewar, T. C. (2003). Determinants of the Corporate Identity Construct: A Review of the Literature. Journal of Marketing Communications, 9(4), 195-220.

Melewar, T. C., Karaosmanoglu, E. ve Paterson, D. (2005). Corporate Identity: Concept, Components and Contribution. Journal of General Management, 31(1), 59-81.

Okay, A. (2003). Kurum Kimliği. İstanbul: Mediacat Yayınları.

Olins, W. (1995). The New Guide to Identity. England: Gower Publishing Ltd. 
Onat, F. (2010). Bir Halkla İlişkiler Uygulama Alanı Olarak Sosyal Medya Kullanımı: Sivil Toplum Örgütleri üzerine Bir İnceleme. Gazi Üniversitesi Illetişim Fakültesi Iletişim Kuram ve Araștırma Dergisi, (31), 103-122.

Özdemir, S., Başel, H. ve Şenocak, H. (2009). Sivil Toplum Kuruluşları (STK)'nın Artan Önemi ve Üsküdar'da Faaliyet Gösteren Bazı STK'lar Üzerine Bir Araştırma. Sosyal Siyaset Konferansları Dergisi, (56).

Parveen, F.; Jaafar, N. I. ve Ainin, S. (2015). Social Media Usage and Organizational Performance: Reflections of Malaysian Social Media Managers. Telematics and Informatics, 32(1), 67-78.

Radomir, L.; PI ıaş, I. ve Nistor, V. C. (2014). Corporate Reputation, Image and Identity: Conceptual Approaches in the Proceedings of the International Conference. Marketing-from Information to Decision (7th Edition). Babes Bolyai University, 219-229.

Rubin, A. ve Babbie, E. (2011). Research Methods for Social Work. (Seventh edition). Brooks/Cole, USA.

Sabuncuoğlu, Z. (2010). İşletmelerde Halkla İlişkiler (10.baskı). Bursa: Alfa Aktuel. Salı, J. B. (2013). Illetişim Araştırmalarında Nitel Yöntemler. (Ed: N. Serdar Sever ve N. Bilge İspir) İletişim Araştırmaları Kitabı İçinde (sf: 136-152). Anadolu Üniversitesi Açıköğretim Yayınları, Eskişehir.

Seoa, H.; Kim, J. Y. ve Yanga S. (2009). Global Activism and New Media: A Study of Transnational Ngos' Online Public Relations, Public Relations Review (35), 123-126.

Sharif, M. H. M.; Troshani, I. ve Davidson, R. (2015). Public Sector Adoption of Social Media. Journal of Computer Information Systems, 55(4), 53-61.

Suher, i. (2012). Kurumsal İtibar Yönetimi. (Ed: Ferruh Uztuğ). Kurumsal Illetişim Kitabı I çinde (sf: 116-137). Anadolu Üniversitesi Açıköğretim Yayınları,Eskişehir.

Sundararajan, B. ve Sundararajan, M. (2012). Like us on Facebook and Follow us on Twitter: Corporate Identity Management Across Social Media Platforms In. C. Cunningham (Ed.), Social Networking and Impression Management (pp. 129146) Lexington Books (2012).

Tsimonis, G.ve Dimitriadis, S. (2014). Brand Strategies in Social Media. Marketing Intelligence \& Planning, 32(3), 328-344.

Tuncer, A. S. (2013). Sosyal Medyanın Gelişimi. (Ed: F. Zeynep ÖZATA). Sosyal Medya Kitabı liçinde (sf: 2-25). Anadolu Üniversitesi Açıöğretim Yayınları, Eskişehir.

Uzunoğlu, E.; Onat, F.; Alikılıç, Ö.A.ve Çakır, S.Y. (2009). Internet Çağında Kurumsal Illetişim. Ankara: Say Yayınları. 
Waters, R. D.; Burnett, E.; Lammb,A. ve Lucas J.(2009). Engaging Stakeholders Through Social Networking: How Nonprofit Organizations are Using Facebook. Public Relations Review, (35), 102-106.

Waters, R. D. ve Jones, P. M. (2011). Using Video to Build an Organization's Identity and Brand: A Content Analysis of Nonprofit Organizations' YouTube Videos. Journal of Nonprofit \& Public Sector Marketing, 23(3), 248-268.

Westcott Alessandri, S. (2001). Modeling Corporate Identity: A Concept Explication and Theoretical Explanation. Corporate Communications: An International Journal, 6(4), 173-182.

Young, J. A. (2017). Facebook, Twitter, and Blogs: The Adoption and Utilization of Socia Media in Nonprofit Human Service Organizations. Human Service Organizations: Management, Leadership \& Governance, 41(1), 44-57.

https://wearesocial.com/uk/special-reports/digital-in-2016/ (Erişim Tarihi: 06.07.2017).

http://www.abs.gov.au/AUSSTATS/abs@.nsf/Lookup/5256.0.55.001Appendix5J ul+2010 (Erişim Tarihi: 05.12.2017).

Esen, H.(2014). Sivil toplum kuruluşlarında iletişim. http://www.ihhakademi. com/wp-content/uploads/2014/01/STKlarda-iletisim.pdf.

Mayfield, A. (2008). What is social media. http://www.icrossing.com/uk/sites/ default/files_uk/insight_pdf_files/What\%20is\%20Social\%2 Media_iCrossing_ ebook.pdf 
